Н. М. Малюга

\title{
«РОЗДІЛЯЙ І ВОЛОДАРЮЙ» ЗАСОБАМИ МОВИ (на прикладі газети «Червоний гірник»)
}

Малюга Н. М. «Розділяй і володарюй» засобами мови (на прикладі газети «Червоний гірник»).

У статті йдеться про дотримання професійних та етичних стандартів представниками регіональних друкованих ЗМІ. Проаналізовано тексти, що містять вербальну агресію, пропагують нетерпимість, нав'язують протистояння, експлуатують ідею «кола своїх», мають дискримінаційний характер. Автор обстоює вимогу достовірності інформації, іiі неупередженого подання, моральності міркувань журналіста. Запропоновано рекомендації щодо зняття інформаційної напруги в кризові періоди.

Ключові слова: ЗМІ, інформаційний продукт, текст, етичні принципи журналістики.

(๑) Н. М. Малюга, 2015. 
Малюга Н. М. «Разделяй и властвуй» средствами языка (на примере газеты «Червоний гірник»).

В статье говорится о соблюдении профессиональных и этических стандартов представителями региональных печатных СМИ. Проанализированы тексты, которые содержат вербальную агрессию, пропагандируют нетерпимость, навязывают противостояние, эксплуатируют идею «круга своих», имеют дискриминационный характер. Автор отстаивает требование достоверности информации, ее беспристрастной подачи, нравственности размышлений журналиста. Предложены рекомендации относительно снятия информационного напряжения в кризисные периоды.

Ключевые слова: СМИ, информационный продукт, текст, этические принципы журналистики.

Maliuga N. M. «Divide and rule» by means of language (for example the newspaper «Chervonyi hirnyk»).

The article refers to abidance by professional and ethical standards of the regional representatives of the printed media. Texts that contain verbal aggression, promote intolerance, impose confrontation, exploit the idea of »circle of friends», have discriminating tone are analyzed. The author exacts faithful information, its impersonal presentation, ethical reflections of journalist. The recommendations regarding the removal of the information tension in times of crisis are suggested.

Key words: media, information product, text, the ethical principles of journalism.

Реально не посівши почесного четвертого місця в ієрархії влади, ЗМІ та створюваний ними інформаційний простір стали полем боротьби для владних гравців. Цінність кожної п'яді завойованого простору значно зростає в кризові періоди для держави, адже нова роль інформації у структурі суспільства сформувала нові, майже необмежені можливості для застосування інформаційних і комунікативних технологій.

Наявність ворога виправдовує багато невідповідностей у сьогоденні. Саме ворог винен у тому, що ситуація $є$ не такою, як планувалося. Сформований образ ворога завжди цементує суспільство, яким тоді легше керувати. Як бачимо, нагнітання ситуації в країні, штучно породжуваний катастрофізм вигідні певним фінансовополітичним і підвладним їм інформаційним групам.

У Рекомендаціях Комітету міністрів Ради Європи «Про захист свободи вираження поглядів та інформації в кризові часи» від 26 вересня 2007 року (термін «криза» тлумачиться як війна, терористичні акти, природні й техногенні катастрофи) у Розділі VI «Обов'язки працівників 3МІ» пункт 23 сформульовано таким чином: «Працівники ЗМІ повинні дотримуватися найвищих професійних і етичних стандартів, і найдужче в кризові часи, пам'ятаючи про свій особливий обов'язок надання громадянам у кризових ситуаціях своєчасної, заснованої на фактах, достовірної й 
вичерпної інформації, водночас зважаючи на права інших громадян, тонкощі їхнього сприйняття, непевність та страх, які вони можуть відчувати» [3]. Далі в пункті 26 працівникам ЗМІ рекомендують враховувати у своїй роботі Рекомендації Комітету міністрів державам-членам № R (97) 21 щодо ЗМI та сприяння культурі толерантності, а також застосовувати, як мінімум, професійні процедури, окреслені в додатку до цієї Рекомендації. У будь-яких ситуаціях, «при яких свобода вираження поглядів та інформації знаходиться під загрозою (наприклад, якщо іï обмежено з причин безпеки), <..> для врегулювання кризисних ситуацій Комітет міністрів ратує за відкритість у поєднанні з відповідальністю» [1, с. 26].

У колективній праці «Жити разом: Посібник з норм Ради Свропи щодо внеску ЗМІ в поліпшення соціальної згуртованості, міжкультурного діалогу, взаєморозуміння, терпимості та демократичної участі» ЗМІ образно названо «сторожовим собакою» демократичного суспільства». Далі йде тлумачення функції 3МІ: «вони здійснюють нагляд за діяльністю органів влади та публікують інформацію про будь-які допущені ними недоліки» [1, с. 12].

Своє дослідження ми здійснили на матеріалах, уміщених у криворізькій міській комунальній газеті «Червоний гірник» (ЧГ), вибірка жовтень - грудень 2014 р. Як відомо, газета є статичним засобом масової інформації, читач (споживач продукту) може зберегти номер, знову прочитати його, часопис забезпечує вихід на конкретну і чітко визначену читацьку аудиторію, інші ЗМI, зокрема телебачення, радіо, цього досягти не можуть. «Червоний гірник» має значний радіус дії та впливу, відтак оприлюднене на його шпальтах слово не буває не почутим. Міська комунальна газета робить суттєвий внесок у проведення публічних дебатів, поширюючи інформацію та ідеї, сприяючи формуванню громадської думки в суспільстві.

Застосування методу суцільної вибірки дозволяє говорити, однак, про стійку тенденцію пропагування нетерпимості до керівних органів держави, формування агресивного, руйнівного образу влади. Напередодні виборів до Верховної Ради газета друкує чимало інтерв'ю кандидатів у депутати 3 позначкою «політична реклама». Політики використовують потужні можливості для маніпуляції громадською думкою за допомогою засобів масової інформації. Наприклад: - Влада замість спасіння економіки воює 3 опозицією <...> Отже, влада впала в справжню істерику; - Влада призначила вибори на 23 жовтня, вони не потрібні людям <...> Влада оголосила вибори, оскільки сподівається зберегти рейтинги, щчо падають; - I не для того полягли на фронтах Великої Вітчизняної війни мільйони () Н. М. Малюга, 2015. $-314-$ 
солдатів, аби через 70 років ӥхній подвиг було забуто, а краӥною правили радикали та екстремісти всіх мастей. А влада відвернулася від усіх ветеранів, пенсіонерів та людей, які все життя віддали на створення нашої країни; «Люди, які знаходяться в заручниках політики діючої влади, повинні відчути, щзо Украйна їх підтримує, щзо украӥнці разом» [ЧГ. - 2014. - №80 (21505) від 23 жовтня. - С. 4]; - Буде сильна команда Кривбасу в парламенті - не допустимо розвалу міста. Не допустимо, аби його намагалися поставити на коліна, затримували кочти, які повинні бути перераховані до місчевого бюджету, а потім піти на поліпшення міського господарства [ЧГ. - 2014. - №80 (21505) від 23 жовтня. - С. 7]. Постійно повторювані ключові слова програмують читачів, точніше - споживачів інформаційного продукту. Спостерігаємо емоційне перенасичення тексту велика кількість образних засобів підміняе фактичний матеріал. У цьому дискурсі активно експлуатується ідея «кола своїх»: формується «своя територія» для лідера і його прихильників; простежується формування когнітивно-лінгвістичної опозиції «свої - чужі».

Цілком погоджуємося з С. Романюк, яка пише: «Загальновідомо, що політика загалом, і окремий політик зокрема, у кожному своєму виступі, доповіді, інтерв'ю, дебатах тощо переслідує ціль утримати владу або здобути іiі у перспективі. Українських політиків характеризує переважно невміле володіння засобами мови на всіх рівнях. А вплив на адресатаопонента часто містить яскраво виражену агресію» [4, с. 165]. Зрозуміло, що чим сильніший супротивник, тим більш асиметричною має бути інформаційна кампанія, яка ведеться проти нього. Асиметричність інформаційної зброї особливо виявляється в негативних контекстах, зокрема звинуваченнях, на які сучасне суспільство реагує досить неадекватно. Тексти, що популяризуються, розраховані лише на своїх прихильників, вони пропагують боротьбу, а не породжують у суспільстві варіант спокою.

Однак у пізніших числах (за листопад-грудень 2014 р.), коли час політичної реклами сплив, спостерігаємо чіткіше окреслення протиставлення «влада в столиці - влада на місцях»: Доки в столиці мудрують над складанням державного бюджету, на місиях доводиться готуватися до розвитку подій за будь-яким сценарієм (назва статті «У Києві призначили тарифи для Кривбасу») [ЧГ. - 2014. - №96 (21521) від18 грудня. - С. 3].

Громадянське суспільство вже звикло до того, що виступи українських політиків «часто не відповідають загальноприйнятому стилю оформлення офіційного повідомлення, а їхній зміст має прихований чи явний маніпулятивний характер, або вони містять вербальну агресію щодо опонента» $[4$, с. 166]. На жаль, ЗМІ виступають у вторинній ролі щодо 
створення інформаційного продукту, первинну роль виконує політична сила, яка надає певній події статусу небезпечної, визначає ії характер як загрозливий. Коли ЗМІ не дозволено брати участь у процесах створення достовірної дійсності, вони лише поглиблюють і поширюють уявлення, задані з боку політикуму. На підтвердження наведемо 2 репліки-запитання журналіста до заступника директора КПТМ «Криворіжтепломережа» (про рентабельність нового тарифу на теплову енергію - Н. М.): - Тобто хочете сказати, щуо вам потрібно було щее більще? I ви, мовляв, щңе й пожсаліли людей, встановивши стільки, а не більше...; - У Києві видніше, щцо коӥться у Кривому Розі, анізс тут на місці? [ЧГ. - 2014. - №85 (21510) від 11 листопада. - С. 4)]. Крім опозиції «влада в столиці (Київ) влада на місцях (Кривий Ріг)», простежуємо нав'язуване протистояння: 3 одного боку, «Криворіжтепломережа», а з іншого, - споживачі.

Український інформаційний простір загалом, «Червоний гірник» зокрема, продукує й підтримує боротьбу міфологій. Різні міфи слугують орієнтиром для представників різних адміністративно-територіальних одиниць (столична еліта намагається поставити на коліна місцеву).

В інтеракціях політиків і утворюваних ними контекстах / текстах відтворюється суспільне середовище, яке складають політичні діячі усіх рівнів. На шпальтах видання експлуатується тема руйнації (щось нагадує відому сентенцію, популярну в римській республіці, - Карфаген має бути зруйнований): «Купка радикалів, які розгромно програли на виборах, при фінансуванні криміналітету намагається зруйнувати стабільність $у$ Кривому Розі, ставлячи під загрозу забезпечення сотень тисяч городян теплом, медикаментами, роботу громадського транспорту та служб життєзабезпечення» - назва: «Криворіжці не підтримують антиправні дії псевдомайдану» [ЧГ. - 2014. - №93 (21518) від 9 грудня. - С. 2]. Пор. російською мовою та сама цитата в статті під назвою «Антикриворожанам не удастся разрушить наш город!» [ЧГ. - 2014. №91 (21516) від 2 грудня. - С. 1].

Газета має свободу публікувати та подавати інформацію, зокрема вдаватися до перебільшень. Цілком погоджуємося 3 твердженням С. Романюк, згідно з яким, «аналізуючи мовлення політика, необхідно «розмістити» його в ситуаційному контексті, щоб змогти відповідно правильно проаналізувати «мовне наповнення» виступу, а також його приховані елементи, напр., персвазію, агресію, маніпуляцію, пропаганду тощо» [4, с. 168]. Інформація та ідеї, які є подразниками для певних кіл, груп населення, повинні мати можливість поширюватися задля охорони «плюралізму, терпимості та широти поглядів, без яких неможливе () Н. М. Малюга, 2015. 
демократичне суспільство», водночас «плюралізм вимагає існування певної рівноваги між (іноді) суперечливими інтересами груп більшості та меншості в суспільстві» [1, с. 14].

Інформація діє на читачів тим сильніше, чим більше в них внутрішньої готовності прийняти ії. Якщо цієї готовності немає, то, за теорією когнітивного дисонансу, споживачі медійного продукту або відмовляють у довірі джерелу інформації, або просто блокують іiі, використовуючи солідніші, надійніші джерела.

Наведемо кілька положень Резолюції 1003 (1993) Ради Свропи «Про етичні принципи журналістики» [2, с. 18-19]. Пункт 2: «Професія журналіста передбачає права й обов'язки, свободи та відповідальність»; пункт 4: «Поширення повідомлень має базуватися на принципі достовірності, що забезпечується відповідними засобами перевірки й доказів, а також на неупередженості подання, опису й розповіді»; пункт 5: «Висловлення міркувань може включати думки або коментарі стосовно загальних ідей чи зауваження відносно повідомлень, що стосуються поточних подій»; пункт 8: [громадянин] «має право вимагати, щоб інформація, яку надають журналісти, подавалася правдиво, якщо мова йде про повідомлення, та чесно, якщо йдеться про міркування, без зовнішнього втручання з боку органів державної влади або приватних осіб»; пункт 13: «...законна повага до ідеологічної спрямованості видавців і власників обмежена абсолютною вимогою щодо достовірності повідомлень і моральності міркувань».

Окремі матеріали, уміщені в «Червоному гірнику», мають виразно дискримінаційний характер, обмежують можливості, права чи привілеї, якими можуть користуватися члени соціуму. Наприклад: Хоч одна шпаринка в законодавстві таки є, якою розумні люди вже скористались, а інші осьось використають. Йдеться про законодавство щодо створення об'єднань співвласників багатоквартирних будинків (ОСББ), себто формального підтвердження нинішнього фактичного статус-кво <..> Так ось, продовжуємо про вдумливих людей, які знають закони і вміють ними користуватися<...> Це де ж такі гроші взяти? Розумні люди ӥх одержують з бюджету, не спустошуючи власної кишені, натомість щзе й отримуючи відремонтовану покрівлю з гарантією <... $>$ Але ж⿻рналістська етика формальним словам вимагає підтвердження фактичними діями <..> Побачив на власні очі $\check{u}$ через фотооб'єктив, оцінив $i$ навіть трохи позаздрив мешканцям иих зовні звичайнісіньких «хрущсовок», у яких живуть справді розумні люди [ЧГ. - 2014. - №87 (21512) від 18 листопада. C. 4]. Стаття має назву «Об'єднання єднає сусідів та гроші», однак протиставлення розумних вдумливих людей та інших свідчить про 
дискримінацію останніх (право на якісні житлово-комунальні послуги), жодним чином не сприяє зняттю напруги між прихильниками ОСББ та їх критиками, крім того, ставить під сумнів обізнаність автора цитованого матеріалу з тим, що таке жсрналістська етика.

Варто розрізняти, чи $є$ емоційно-забарвлені слова самі собою мовою ненависті. Це може бути ознакою стереотипності, це може бути ознакою емоційності.

Слід обережніше підходити до номінації осіб, які внаслідок обгрунтованих побоювань стали жертвою переслідувань за певними ознаками, скажімо, належності до певної соціальної групи або політичних переконань, перебувають за межами території постійного проживання (стосується тимчасово не контрольованої Україною території). Так, якщо вжито слово біженці (словникове визначення: люди, що залишають місце свого проживання під час війни або стихійного лиха), то синонімічний ряд із словом гості, та ще й донецькі, може викликати небажані асоціації. Наприклад: Стосовно ж передачі приміщення КEI (про рішення щодо передачі головного корпусу Криворізького економічного інституту Донецькому національному університету економіки i торгівлі ім. Михайла Туган-Барановського - Н. М.), думаю, проблема загострилась не тому, щуо донецьким біженцям тут не раді, а тому, щчо питання вирішувалось не зовсім відкрито, без участі педагогів і студентів <..> У Кривому Розі багато приміщень, $i$ знайти альтернативу для донецьких гостей можна без шкоди для КЕI [ЧГ. - 2014. - №95 (21520) від 16 грудня. - С. 5]. У наведеному контексті слід було вжити словосполучення вимушені переселенці, що має прозору внутрішню форму. Проаналізований приклад (сподіваємося, що це недогляд) дає алюзію на казку про Зайчика, до якого в хатинку попросилася тимчасово пожити Лисичка, а потім вигнала господаря. Аби не виникало подвійного контексту, необхідно все називати своїми іменами.

В окремих випадках спостерігаємо дискримінацію за гендерною ознакою. Наприклад: Керівниці вищу (в. о. ректора та заступник - Н. М.) докладно розповіли про його важке становище, розкол у викладацькому складi, переслідування педагогів і студентів з боку керівництва так званої «ДНР». Жінки попросили виділити Дон НУЕТ будь-яке окреме примімення та гуртожиток $i$ запевнили, що не претендують саме на головний корпус KEI, який став каменем спотикання [ЧГ. - 2014. - №95 (21520) від 16 грудня. - С. 5]. Не вважаємо коректним називати представників ректорату за статевою ознакою. У професійному середовищі вживається офіційно присвоєне вчене звання. Важко уявити, аби в подібному контексті в. о. С Н. М. Малюга, 2015. 
ректора та його заступника назвали чоловіками (на зразок Перед присутніми виступили міський голова та секретар облради. Чоловіки наголосили...). У такому разі соціокультурна роль особистості нівельована, на чільне місце висунуто біологічні відмінності. Під сумнів ставляться ділові якості управлінців; виявляється, що жінка на посаді може вирішити складну ситуацію, лише викликавши до себе жаль (важжке становище, переслідування, попросили, будь-яке, запевнили, не претендують), тобто транслюється модель сімейно-побутових відносин. Це яскравий приклад гендерної асиметрії в офіційному спілкуванні.

Місцеві ЗМІ здатні «створювати простір для діалогу, задовольняючи специфічні потреби або вимоги певних груп громадянського суспільства та виступаючи чинником соціальної єдності та інтеграції» [1, с. 32].

Спеціальним зобов'язанням ЗМІ є сприяння культурі терпимості й розуміння, натомість аналізовані матеріали переконують нас у зворотньому: Від керівництва міста вийшов поспілкуватися 3 мітингувальниками секретар міськради Сергій Маляренко, але на його адресу від однієї з учасників акції пролунали погрози підняти зеків [ЧГ. 2014. - №93 (21518) від 9 грудня. - С. 2]. Ілюстрація містить вербальну агресію, нав'язує протистояння, має дискримінаційний характер. Дискримінацію раніше засудженої особи підтримує ідеологія як влада ідей.

Політичний дискурс має безпосередній вплив на формування інших дискурсів, зокрема дискурсу 3MI, а також на взаємини між державою, економікою і громадянським суспільством. Зіткнення думок, переконань, вектори яких спрямовані в протилежні сторони, стає основним інформаційним конфліктом в інформаційному полі.

У Резолюції 1003 (1993) Ради Свропи «Про етичні принципи журналістики» інформацію визначено основоположним правом громадянина. Див. пункт 15: «Інформаційні організації мають ставитися до інформації, як до основоположного права громадянина, а не як до товару» та пункт 21: «Журналістика не повинна змінювати правдиву й неупереджену інформацію або чесні думки, використовувати їх на користь 3MI, намагаючись створити чи сформувати громадську думку, оскільки законність журналістики грунтується на ефективній повазі основоположного права громадян на інформацію як складовій поваги демократичних цінностей» [2, с. 19]. Міркування журналіста обов'язково $\epsilon$ суб'єктивними, однак слід дотримуватися, щоб міркування висловлювалися чесно й відповідно до етичних засад.

Не може бути вільного і демократичного суспільства без вільної 
преси, тому політичні діячі, представники владних структур, різні компанії повинні погоджуватися 3 опублікуванням незручної або неприємної для них інформації. ЗМІ слід послідовно застосовувати принцип верховенства суспільного інтересу, навіть коли ставиться під загрозу повага до приватного життя або збереження так званих секретних матеріалів [1, с. 50-51]. Журналістика є несумісною 3 журналістськими кампаніями, що проводяться на підставі заздалегідь випрацюваних позицій і спеціальних інтересів. Засобам масової інформації не треба експлуатувати якість або зміст повідомлень чи міркувань задля збільшення кількості читачів і, відповідно, прибутків.

Нині назріла потреба здійснювати моніторинг мови ЗМІ, щороку публікувати дослідження фахівців, зроблені постфактум, про достовірність поширюваної інформації. Це слугуватиме показником довіри, який громадянин зможе використовувати як підказку щодо етичного стандарту, досягнутого кожним окремим засобом масової інформації (у нашому випадку - криворізькою міською комунальною газетою «Червоний гірник») чи навіть кожним окремим журналістом.

\section{Література}

1. Жити разом : Посібник з норм Ради Європи щодо внеску ЗМІ в поліпшення соціальної згуртованості, міжкультурного діалогу, взаєморозуміння, терпимості та демократичної участі / Вид. під кер. Я. Ланж. - Рада Європи, 2010. - 62 с.

2. Рада Європи. Парламентська асамблея. Резолюція 1003 (1993) «Про етичні принципи журналістики» // Стандарти Ради Європи у сфері медіа : Законодавчий бюлетень. - К., 2005. - С. 18-20.

3. Рекомендації ради Європи щодо роботи медіа в кризові часи [Електронний pecypc]. - Режим доступу : osvita.mediasapiens.ua

4. Романюк С. Формулювання комунікату в українському політичному дискурсі : невміння чи свідоме маніпулювання? / С. Романюк // Studia ucrainica Varsoviensia. Warszawa : Wydawnictwa uniwersytetu Warszawskiego, 2015. - C. 165-178.

Стаття надійшла до редакиії 25.07.2015 p. 